\title{
Die waarde van Akteur-Netwerk-Teorie en 'n etnografiese navorsingstrategie vir die ondersoek van opvoedkundige tolking aan die Universiteit Stellenbosch
}

\author{
Carmen Brewis \\ Departement Afrikaans en Nederlands, Universiteit Stellenbosch, Suid-Afrika \\ E-pos: carmenb@sun.ac.za
}

\section{Opsomming}

Namate die sosiale wending in vertaalstudie toenemend inslag gevind het, het navorsers begin fokus op die menslike agente betrokke by vertalings, en op die sosiale voorwaardes wat in die reële wêreld geld. Navorsers het al hoe meer die waarde begin insien van meer prosesgeoriënteerde navorsing in vertaalstudie. Die Franse sosioloog Bruno Latour se AkteurNetwerk-Teorie (oftewel ANT) laat die navorser die objek van navorsing nie as substantiewe verskynsel beskou nie, maar as 'n netwerk van verhoudinge deur 'n studie te maak van die betrokke mense én objekte (akteurs en aktante) en die wisselwerking tussen hulle. Binne hierdie teoretiese raamwerk is etnografie of ' $n$ etnometodologie besonder gepas omdat dit die navorser nader bring aan die beleefde ervaring. Opvoedkundige tolking, of mondelinge tolking in klaskamers vir niegehoorgestremde studente, is ' $n$ innoverende toepassing van tolking, en ook 'n grootliks onontginde kennisveld. Dit is as taalmodus by die nuwe Taalbeleid van die Universiteit Stellenbosch (US 2016) ingesluit ter wille van die praktiese uitvoerbaarheid van meertaligheid. In die praktyk is opvoedkundige tolking egter dikwels onderhewig aan onrealistiese verwagtinge, en die waarde daarvan in 'n opvoedkundige konteks bly kontensieus. Empiriese navorsing in getolkte klasse binne 'n raamwerk van ANT kan moontlik lig werp op die wisselwerking tussen die onderskeie faktore in opvoedkundige tolking en hoe hulle funksioneer. Hierdie artikel ondersoek die waarde van ANT na aanleiding van data wat gedurende veldwerk in 36 getolkte lesings aan die Universiteit Stellenbosch ingesamel is. Dit toon hoe 'n etnometodologie binne die teoretiese raamwerk van ANT die navorser in staat stel om verder en dieper te beskryf; om gebeure, verwantskappe, verskynsels en situasies wat tot nog toe onvertel was, aan die lig te bring. Uiteindelik kan hierdie bevindings waardevol wees vir taalimplementering aan die Universiteit Stellenbosch en die soeke na prakties uitvoerbare meertaligheidspraktyke aan Suid-Afrikaanse universiteite.

Trefwoorde: Akteur-Netwerk-Teorie, etnografie, opvoedkundige tolking, sosiologie, tolkstudie 


\title{
The value of Actor-Network Theory and an ethnographical research strategy in exploring educational interpreting at Stellenbosch University
}

\begin{abstract}
As the social turn in translation studies progressively gained acceptance, researchers started focusing on the human agents involved in translation, and on the social conditions that apply in the real world. Researchers have increasingly come under the impression of the value of more process-oriented research in translation studies. French sociologist Bruno Latour's ActorNetwork Theory (or ANT) allows the researcher to consider the object of study not as a substantive phenomenon, but as a network of relationships by studying both the humans and objects (actors and actants) involved, as well as the interaction between them. Within this theoretical framework, ethnography or an ethnomethodology is particularly useful in bringing the researcher closer to the lived experience. Educational interpreting, or verbal class-based interpreting for students who are not hearing-impaired, is an innovative application of interpreting and constitutes a largely unexplored field of study. It has been included as a language option in the new Language Policy of Stellenbosch University (SU 2016) to facilitate practicable multilingualism. In reality, however, educational interpreting is often subject to unrealistic expectations, and its value in an educational context remains contentious. Empirical research in interpreted lectures within a framework of ANT may possibly shed light on how the various factors at play in educational interpreting interact and operate. This article examines the value of ANT with reference to data that were collected in 36 interpreted lectures at Stellenbosch University. It shows how an ethnomethodology within the theoretical framework of ANT broadens and deepens the researcher's understanding and uncovers previously untold events, relationships, phenomena and situations. Ultimately, these findings may prove useful for language implementation at Stellenbosch University and the pursuit of practicable multilingualism at South African universities.
\end{abstract}

Keywords: Actor-Network-Theory, educational interpreting, ethnography, interpreting studies, sociology

\section{Inleiding}

Deur die werksaamhede van die Tolkdiens van die Universiteit Stellenbosch (US) Taalsentrum word daar daagliks waardevolle data in die produksieproses van getolkte lesings in universiteitsklaskamers gegenereer. In hierdie konteks verwys tolking na intydse gesproke tolking deur ' $n$ tolk wat in die klaskamer teenwoordig is. Opvoedkundige tolking vorm sedert 2014 as aparte taalmodus deel van die Taalbeleid van die US (US 2016) en is ingesluit ter wille van inklusiwiteit en die bevordering van meertaligheid. In kontekste waar tolking tradisioneel plaasvind, is hierdie data normaalweg moeilik om in te win vanweë die 'onsigbaarheid' van die tolk, die geslote aard van die konteks waarin tolking plaasvind, en die vlietende aard van die getolkte teks. Terwyl opvoedkundige tolke van lesing tot lesing vir hulle gebruikers tolk, bly hulle bewus van hoe verskillende faktore, sowel menslik as niemenslik, die kommunikasie medieer en die effektiwiteit van die produk beïnvloed. Maar wie of wat is hierdie faktore, en wat is die verhouding of wisselwerking tussen hulle?

Binne die sosiologiese vertaalteoretiese perspektief is die fokus op die realiteite van vertaling (of tolking) en die agente betrokke by tolking as 'n sosiale proses. Met 'n prosesbenadering is 
die vraag nie met watter doel vertalings geskep word nie, maar eerder meer pragmaties: Hóé doen vertalers (of tolke) dit? Skrywers soos Buzelin (2005:209) wys byvoorbeeld op die waarde van 'n ondersoek na die skepping van vertalings (of tolking) as 'n produksieproses om die produk en die keuses daaragter beter te verstaan. Pöchhacker (2006:229) stem hiermee saam en raai navorsers aan om betrokke te raak by die konteks en die "sosiale realiteit" van hulle navorsingsobjek. Hy stel voor dat 'n metodologie hiervoor verkieslik uit die sosiale wetenskappe moet kom. Buzelin (2005:193) bespreek die werk van twee Franse sosioloë, Pierre Bourdieu en Bruno Latour, en meen dat Latour se Akteur-Netwerk-Teorie ${ }^{1}$ (ANT) besonder waardevol kan wees om die strategieë, onderhandelinge en konflikte in 'n vertaal- of tolkkonteks aan die lig te bring.

Hierdie artikel ondersoek die waarde van ANT en 'n etnografiese navorsingstrategie deur gebruik te maak van data wat ingesamel is gedurende tolking in die Fakulteit Regsgeleerdheid aan die US in die eerste kwartaal van 2017. Die ondersoek kan dalk waardevolle insig bied in die ware aard van opvoedkundige tolking en die sosiale voorwaardes wat in die vervaardigingsproses van 'n getolkte lesing geld.

\section{Akteur-Netwerk-Teorie en tolkstudie}

Gad en Bruun Jensen (2010:58) wys daarop dat ANT die wêreld as 'n samestelling van prosesse postuleer. 'n Proses bestaan uit 'n netwerk (of 'werknet') akteurs wat almal saamwerk om die uiteindelike produk te vorm. Fenomene (soos tolking) word 'in die proses' of 'in aksie' beskou, terwyl daar gefokus word op wat die rolspelers of akteurs in die proses (van tolking) doen. Die term 'akteur' verwys na enigiets of enigiemand wat 'n invloed het of verbindings veroorsaak. 'Aktant' is ' $\mathrm{n}$ tegniese term wat sowel menslike as niemenslike akteurs insluit. ${ }^{2}$ Wat akteurs betref, maak Latour (2005:37) 'n onderskeid tussen mediators ("mediators") en tussengangers ("intermediaries"). Waar eersgenoemde 'n verandering in die netwerk veroorsaak en belangrik is vir ANT, het 'n tussenganger geen werklike effek op die netwerk nie, en laat 'n beperkte spoor. Een van die grootste innovasies van ANT is die klem op niemenslike akteurs. In opvoedkundige tolking verwys dít nie slegs na mikrofone, truprojektors en MS PowerPointskyfies nie, maar ook na idees, vaardighede, taal en emosie. Die navorser moet hieraan aandag gee in soverre dit ' $n$ spoor in die netwerk laat en die proses en produk van opvoedkundige tolking beïnvloed. ${ }^{3}$

In vertaling (sowel as tolking) neem agente dikwels besluite op grond van intuïsie of praktiese ervaring. Hierdie proses is moeilik om te beskryf, veral as dit retrospektief gedoen word. ANT behels dat die navorser die objek van ondersoek byna raam vir raam 'in die proses' of 'in aksie' beskou. So 'n ondersoek sal die verskillende akteurs aan die lig bring. Mol (2010:257) wys

1 In sy invloedryke werk Reassembling the Social (2005) noem Bruno Latour sy alternatiewe sosiale teorie "Actor-Network-Theory". Die gebruik van koppeltekens verskil van bron tot bron. In Duits word die term Akteur-Netzwerk Theorie gebruik en in Deens aktor-netvaerksteroi. Vir die Afrikaanse spelling het die skrywer op sowel koppeltekens as hoofletters besluit (ter wille van die akroniem ANT).

2 Ter wille van konsekwentheid sal die term 'akteur' deurgaans gebruik word. In ANT word die twee terme afwisselend gebruik.

3 Volgens Latour (2005:8) is dit die ondersoeker se primêre taak om hierdie spore te volg. Sosiologie is nie iets wat bestaan of gepostuleer kan word nie; dit is bloot sigbaar in die spore wat in die netwerk gelaat word. 
daarop dat 'n akteur nie met presisie gedefinieer kan word nie. Gad en Bruun Jensen (2010:58, 61) sê in dié verband:

Things are what they are because they are done that way by actors relating to other actors. [...] The ANT concept of actor does not refer to actors with predefined characteristics, but underscores the many ways in which actors bestow agency on one another.

Buzelin (2007:165) beskou ANT in sy 'sterkste' vorm as 'n teorie, en in sy 'swakste' vorm as 'n metode. As ' $n$ metode is dit uiters geskik vir die bestudering van enige nuwe ontwikkeling in kommunikasie (Buzelin 2005:212). Van 'n ANT-metodologie vir vertaal- (of tolk-)teorie sê sy die volgende (2005:205):

[T]he observation, recording and analysis of interpreting practices locally, over a sufficient period of time, will generate data that should enable us to get a better idea of who participates, who/what are the actors and how they negotiate their position.

Callon (in Buzelin 2005:198) stem hiermee saam en sê dat 'n ondersoek na tolking volgens 'n ANT-raamwerk slegs behoorlik deur 'n etnografiese studie gedoen kan word. 'n Etnografiese strategie impliseer dat opvoedkundige tolking ondersoek word as 'n sosiaal-kulturele praktyk wat in 'n bepaalde konteks plaasvind. Met verwysing na Geertz (1973) reken Flynn (2010:118) dat dit in 'n etnografiese studie in vertaal- of tolkteorie onvermydelik is dat die ondersoeker die veld betree om te sien wat die subjekte van die studie elke dag moet deurleef, wat met hulle gebeur, watter formules hulle vir hulleself skep, en wat die voorwaardes en idiologieë is wat hulle lewens rig. Hieroor sê Gad en Bruun Jensen (2010:61): "ANT researchers follow the making and breaking of associations and allow the vocabulary of locals to seriously influence the travel report." Dit behels noodwendig dat die navorser dáár moet wees, ín die veld, tússen haar navorsingsubjekte, op gewóne dae, om hulle leefwêrelde eerstehands te ervaar. Pollner en Emerson (2001:124) wys ook daarop dat die etnograaf dikwels sélf 'n rolspeler in die werkplek is. Die navorser moet as't ware self in staat wees om betekenis 'in te vul'. Garfinkel (in Pollner en Emerson 2001:124) meen dat die navorser wat nie aan hierdie vereistes voldoen nie, dalk kan faal om belangrike aspekte van die geleefde wêreld raak te sien, en dit selfs kan verwring. Die feit dat die navorser'n rolspeler in die werkplek is, verleen dus geldigheid en betroubaarheid aan die ondersoek.

\section{Metodologie}

Die studiekonteks vir hierdie artikel is die Fakulteit Regsgeleerdheid aan die US. Die skrywer het haar regsopleiding in hierdie fakulteit ontvang en self in dié vakrigting gespesialiseer. Sy beskik daarom oor agtergrondkennis wat haar waarnemings kon oriënteer. Sy self het ook deurgaans saam met 'n kollega as tolk in al die lesings opgetree. ${ }^{4}$ Albei tolke beskik oor ' $n$ LLB-kwalifikasie en werk reeds sowat vier en 'n half jaar as opvoedkundige tolke aan die US.

Die steekproef bestaan uit veldwerk in 36 getolkte lesings in vier modules - naamlik Strafreg 171, Inleiding tot die Reg 171, Inheemse Reg 171 en Privaatreg 171 - in die eerste kwartaal van 2017. Gedurende die tolkproses het die navorser telkens 'n woord of idee

4 Tolke werk normaalweg in pare en tree as hulptolke vir mekaar op. Om etiese redes word die ander tolk se naam verswyg. Gebeure in die tolkproses word ook nie met enige bepaalde tolk verbind nie. 
neergeskryf en dan later na aanleiding daarvan uitgebreide aantekeninge in dagboekstyl gemaak. Dit is vervolgens uit haar eie agtergrondkennis van die konteks, sowel as insigte uit gesprekke met haar hulptolk en dié se waarnemings aangevul. Al hierdie aantekeninge is in teksvorm omgeskakel.

In 'n iteratiewe proses is die teks deurgewerk en die akteurs geïdentifiseer. Elke akteur is afsonderlik met 'n afkorting in die teks aangedui. Omdat ANT enigiets wat aksie veroorsaak as akteur beskou, was daar aanvanklik veelvuldige akteurs in die netwerk sigbaar. Hierdie akteurs is later in kategorieë ingedeel: So byvoorbeeld het "artefakte" Google Translate, mikrofone en die Taalbeleid ${ }^{6}$ ingesluit.

Wat die tolk as akteur betref, moes 'n onderskeid gemaak word tussen of die tolk as gevolg van haar taalvaardigheid, tolkvaardigheid, vakkennis, persoonlikheid of moontlik in haar hoedanigheid as hulptolk figureer. Die navorser het hierna getel hoeveel maal die onderskeie akteurs voorgekom het. Dit het ook duidelik geword dat sekere akteurs telkens sáám in die netwerk figureer. In hierdie verband meen Buzelin (2007:163) dat dit belangrik is vir navorsers om in gevallestudies ondersoek in te stel na hoe dikwels sekere praktyke (of akteurs) waargeneem word, en om dít dan te vergelyk met die werklike ervaring sowel as met teoretiese idees wat oor die onderwerp van die ondersoek bestaan.

\section{Akteur-Netwerk-Teorie as metode}

As deel van 'n ANT-metodiek het die navorser ervaar dat sy telkens die ondersoek 'stadiger moes maak'; dat sy nugter moes dink oor die rolspelers wat 'n spesifieke spoor in die netwerk laat. Kantaantekeninge oor haar ervaring was baie waardevol en het gehelp om inligting of rolspelers in konteks te plaas (posisie in die netwerk in verhouding tot ander akteurs). Dit was nie altyd duidelik watter akteur aan die werk was of die spoor gelaat het nie. Dikwels moes sy die spoor verder terugneem en terugwerkend vasstel waar dit vandaan kom en watter akteur dit veroorsaak het. Latour (2005:60) verduidelik juis dat kousaliteit terugwerkend gemaak moet word. Dit was nie van veel waarde om met intensionele handeling en oorsaaklikheid te werk nie; om op aksie te fokus en bloot die akteurs in die netwerk te volg was meer sinvol. Die navorser het eerstehands ervaar dat sy enige gevolgtrekkings, waardeoordele, gevoelens en teorie van die rolspelers self moes skei, en dat konsepte soos 'rol', 'mag' en 'kwaliteit' vermy moes word. Latour (2005:8) waarsku ook teen konsepte wat nie 'n verduideliking gee nie, maar wat self ' $n$ verduideliking verg.

Dieselfde akteur het soms verskillende gevolge in die netwerk veroorsaak, of het soms as oorsaak en soms as gevolg gefigureer. Dit het duidelik geword dat akteurs soms in die netwerk as mediators optree en 'n belangrike rol in die netwerk speel, en ander kere bloot tussengangers is. Verbande of ' $\mathrm{n}$ soort wisselwerking tussen akteurs het herhaaldelik na vore gekom. Na gelang van die konfigurasie van rolspelers op 'n sekere node in die netwerk, was die wisselwerking én die gevolge anders. Wanneer Latour (2005:143) oor die netwerk praat, verduidelik hy dat die netwerk, of 'werknet', bloot die instrument is wat die onderwerp van die

\footnotetext{
5 In ANT verwys die term 'artefak' gewoonlik na 'n tegnologiese rolspeler, maar dit word nie konsekwent daarvoor gebruik nie. Dit kan ook verwys na enige niemenslike akteur wat 'n rol in die netwerk speel.

6 Die Taalbeleid verwys na die Taalbeleid van die US (2016) wat op 1 Januarie 2017 in werking getree het.
} 
ondersoek beskryf. Hoe die verskillende akteurs in die netwerk van 'n getolkte lesing figureer, verleen insig in die proses en produk van 'n getolkte lesing.

\section{Bespreking van die data}

In die netwerkfragment waarop die ondersoek fokus, was die twee sigbaarste akteurs terminologie en die tolk. Ander akteurs wat dikwels in die netwerk sigbaar was, was die dosent, en artefakte soos die Taalbeleid, MS PowerPoint-skyfies, selfone en oorfone. Administratiewe aspekte het eweknieterugvoer en die afneem van 'n presensielys ingesluit. Akteurs soos studente of lokale was minder sigbaar in die netwerk, en sommige akteurs (soos aanlyn woordeboeke) het slegs enkele kere gefigureer. Dit was opmerklik dat etiekkodes as akteur glad nie in die netwerk sigbaar was nie.

'n Verdere waarneming was dat tolke duidelik verskillend in die netwerk figureer na gelang van hulle vakkennis, taalvaardigheid of spesifieke hantering van die doeltaal, in dié geval Afrikaans. Die tolk is byna sonder uitsondering naas terminologie in die netwerk geposisioneer, en in die meeste gevalle as vakkundige, soms as taalvaardige, en in enkele gevalle as tolkvaardige persoon. ${ }^{7}$

Een van die vernaamste gewaarwordinge was watter prominente rol die tolk as vakspesialis vervul. Terme soos corporeal is sonder huiwering getolk as 'stoflik', indictment as 'klagstaat', en satisfaction as 'genoegdoening'. Latynse frases of terme soos contra bonos mores of restitutio in integrum is geantisipeer en korrek uitgespreek. ${ }^{8}$ Tolke kon komplekse sinskonstruksies sintakties korrek in die doeltaal weergee. Hulle kon ook referente korrek antisipeer. Deur vakkennis kon die tolk akteurs soos die dosent se stem en die akoestiek van die lokaal verreken. Die dosent verwys byvoorbeeld na 'n regter in die konteks van die Konstitusionele Hof, maar die tolk hoor net 'n 'sch'-klank. Sy antisipeer die regter se van korrek as 'Chaskalson'. Eweneens besef die tolk dat 'n onhoorbare frase voor die woord claim waarskynlik particulars of claim moet wees, en tolk dit korrek as 'besonderhede van vordering'. Tolke het uit die posisie van die head note en flynote in die gedrukte hofsaak verstaan dat dit onderskeidelik na die kopnota en sleutelwoorde verwys, en kon dit dus korrek tolk, hoewel hulle nie die Engelse terme geken het nie.

Tolke as vakkundiges speel ' $\mathrm{n}$ spesifieke rol in die netwerk in wisselwerking met die dosent as akteur. As die dosent oor 'n term twyfel en na die tolke draai vir hulp, kan die tolke die korrekte vertaalekwivalent gee. Die dosent gebruik die term concurrent, kyk na die tolk en vra hoe sy dit getolk het. Die tolk antwoord: "Konkurrent." Die dosent glimlag en sê: "Mooi!" Die tolke herken foute op die MS PowerPoint-skyfies, soos "regsaanwysigingsreëls" in plaas van 'regsaanwysingsreëls', en bring dit onder die dosent se aandag. As die dosent die Afrikaanse term vir notification as "bekendmaking" op die skyfies aandui, tolk die tolk die term korrek as 'kennisgewing'. In 'n gesprek met die gebruikers oor die waarde van tolking blyk dit dat hulle tolking gebruik omdat die tolke die korrekte vakterminologie ken: "Ons luister vir (sic) die terme omdat alle dosente nie Afrikaans ewe goed ken nie en hulle nie altyd die terme reg gebruik nie."

\footnotetext{
7 Om na tolke as vakkundiges (of taalkundiges) te verwys impliseer in ANT-terme dat die tolk as akteur in die netwerk naas vakkennis geposisioneer word of in 'n spesifieke verhouding tot die bron- of doeltaal staan.

8 Antisipering is ' $n$ tolkstrategie in die begripvormingsfase van die tolkproses. Vakkennis het die tolke in hierdie studie gehelp om dié strategie telkens suksesvol te gebruik.
} 
'n Hoë vlak van taalvaardigheid help die tolk om die korrekte sintaksis en voorsetsels te gebruik en nievakterme korrek te vertaal. Tolke slaag daarin om Afrikaanse vertaalekwivalente te gee vir traded ('verhandel'), parastatal ('semistaat'), support ('rugsteun'), daunting ('oorweldigend') en profound ('diepgaande'). Tolke begryp dat sekere terme vanweë die verwantskap tussen Engels en Afrikaans op 'n sekere manier hanteer moet word, en nie direk vertaal kan word nie. Wanneer die dosent sê: "You can count on it", tolk die tolk: "Jy kan jou geld daarop sit." Die gemaklikheid en vaardigheid wat met 'n moedertaal gepaardgaan, stel tolke in staat om oplossings te vind. ${ }^{9}$

Dosente se vaardigheid in die brontaal en hantering van taal vereis in sekere gevalle 'n hoë taalvaardigheidsvlak van tolke. 'n Dosent wat 'n Engelsmoedertaalspreker is en oor 'n uitgebreide Engelse woordeskat beskik, gebruik frases soos trusted pistol, maidens of chastity of thin edge of the wedge. Na gelang van hoe die dosent as Engelsmoedertaalspreker taal 'in aksie' gebruik, word daar dus 'n wisselende vlak van taal- en tolkvaardigheid van tolke vereis. Ook studente as taalvaardige of nietaalvaardige sprekers beïnvloed die eise wat aan die tolke gestel word. Vrae is soms onsamehangend en swak geformuleer. Die tolk moet dit begryp en in 'n toepaslik vertaalde vorm weergee. Soms vereis dít 'n kombinasie van taalvaardigheid en tolkvaardigheid.

Wanneer tolke met byna onvertaalbare frases en onverwagse uitdrukkings gekonfronteer word as 'n dosent byvoorbeeld uit 'n hofsaak voorlees of die feite van 'n saak vinnig en soms geanimeerd weergee, moet tolke die vaardigheid hê om met strategieë soos segmentering (chunking $)^{10}$ vir hulleself ruimte te skep en betekenis korrek en op 'n gepaste toon aan hulle gebruikers oor te dra. Dikwels sal tolke parafraseer of antisipeer om hierdie tipe uitdagings te hanteer. Suksesvolle antisipering en parafrasering hou weer verband met vakkennis. ${ }^{11}$ In sekere gevalle het hierdie faktore weer 'n te kort volgafstand by tolke tot gevolg gehad of 'n onnatuurlike ritme en gejaagde toon veroorsaak.

In haar rol as passiewe tolk is die tolk 'n belangrike agent in die netwerk, en dit was opmerklik hoe dikwels juis hierdie aspek van die proses van wesenlike belang is om 'n kwaliteitproduk te produseer. Hoe 'n tolk as hulptolk figureer, hang af van verskillende faktore, waaronder haar persoonlikheid, taalvaardighede, algemene kennis, voorbereidheid, en hantering van artefakte (soos woordelyste of notaboeke vir terme). Tog hang dit ook af van die wisselwerking tussen die twee tolke: hoe hulle saamwerk en of daar samehorigheid en vertroue tussen hulle bestaan. In die proses kon 'n mens duidelik sien hoe die verhouding tussen die tolke die hantering van probleme in kommunikasie beïnvloed. Hierdie verhouding bepaal of hulle saamstem oor kwessies en moontlike oplossings, hoe hulle verskille oor taal hanteer, en of hulle met vrymoedigheid terme en oplossings aan mekaar voorstel. Dit het 'n positiewe of negatiewe invloed op hulle interaksie met objekte soos aanlyn woordeboeke (op hulle selfone) of die hantering en oorgee van die mikrofoon.

9 Hoewel die data oor direksionaliteit in tolking teenstrydig is, strook hierdie gewaarwording met skrywers soos Pöchhacker (1996) en Chang (2005), wat bewyse gevind het van groter linguistiese korrektheid en idiomatiese taalgebruik wanneer tolke in hulle eerste taal tolk.

10 Hierdie strategie word in die produksiefase van tolking gebruik, en behels dat ' $n$ lang string inligting in kleiner segmente herrangskik en gereproduseer word.

11 Chernov (2004:93) beskryf studies wat bevind het dat hoër vlakke van begrip (by die tolk) die graad van weglaatbaarheid ("redundancy") in die teks, en daarom ook die potensiaal vir die gebruik van die antisiperingstrategie, verhoog. 
In die tolkproses word die tolk wat tweede tolk deur die lewering van die eerste tolk gerig. Indien daar nie genoeg vertroue tussen hulle is nie, of indien die tweedetolk afgetrokke is en nie aktief luister nie, is die waarde hiervan beperk. Administratiewe take wat gedurende die tolkproses vervul moet word (soos die afneem van 'n presensielys of voltooiing van eweknieevaluering) kan die tweede tolk se aandag aflei en haar waarde as passiewe tolk beperk.

Die dosent is 'n sigbare akteur in die netwerk, en veral haar klasgeestyl of hantering van taal beïnvloed die netwerk. Sommige dosente maak dikwels van humor gebruik, of het unieke style wat moeilik is om in tolking te verreken. Humor kan verlore gaan en 'n negatiewe effek hê op die gevoel van insluiting wat die gebruikers ervaar. Dosente se onkunde oor en vertroue of wantroue in tolking kring uit na hulle studente. 'n Dosent onderneem byvoorbeeld voor 'n klas teenoor die Afrikaanse studente om inligting in Afrikaans te vertaal, en betrek nie die tolke (of die gebruikers) by die gesprek nie. Ná die tyd vra 'n student die tolke of tolking nog voortgaan en of gebruikers daarvoor moet betaal. Dosente se interpretasie en toepassing van die Taalbeleid speel ook 'n rol deurdat herhaling van inligting in Afrikaans dit in sommige gevalle onnodig maak vir studente om tolking te gebruik. In 'n klas met sowat 45\% Afrikaansmoedertaalsprekers waar inligting in Afrikaans herhaal is, was daar byvoorbeeld aan die einde van die eerste kwartaal slegs een konsekwente gebruiker van tolking oor.

Naas die menslike akteurs, was die Taalbeleid die mees sigbare akteur in die netwerk. ${ }^{12}$ Die Taalbeleid van die US bepaal in paragraaf 7.1.4.1 (US 2016) dat "alle inligting in ten minste Engels oorgedra moet word". Waar tolke tevore uit Afrikaans in Engels getolk het, het die Taalbeleid nou meegebring dat tolke in alle regsmodules uit Engels in Afrikaans tolk. Albei tolke is Afrikaansmoedertaalsprekers en tolk nou vir die eerste maal in hulle eerste taal. Daar was onmiddellik die gewaarwording dat 'n mens meer met jou stem kan oordra en meer natuurlik tolk. Goeie vertaalekwivalente was meer geredelik beskikbaar. Verduideliking of parafrasering as tolkstrategie was nou makliker omdat tolke uit 'n groter repertoire van woorde kon kies. Die tolk se vaardigheid in die doeltaal het hier'n rol gespeel. Waar die tolking vanweë die dosent se vinnige praatspoed of onbekende terme uitdagend was, het tolke soms Engelse woordorde of voorsetsels gebruik, soos "en omdat artikel 7(2) was toepaslik" in plaas van 'toepaslik was', "beskerm mense van hulleself" in plaas van 'teen hulleself', en "in die inhoud ingaan" in plaas van 'op die inhoud ingaan'.

Die gebruik van ANT, as teorie sowel as metode, het getoon watter verskillende akteurs in die netwerk sirkuleer. Latour (2005:12) merk in dié verband op:

Follow the actors themselves, try to catch up with them in order to learn from them what the collective existence has become in their hands and which accounts could best define the new associations that they have been forced to establish.

\section{Voorlopige waarnemings}

Een van die vernaamste gewaarwordinge was dat dieselfde akteur verskillend figureer na gelang van sy of haar posisie in die netwerk. 'n Tolk moet 'n student se vraag tolk in 'n groot lokaal met swak akoestiek terwyl die student boonop sag en onsamehangend praat en onduidelik artikuleer. 'n Dosent wat die uitdagings van tolking verstaan, of wat vanweë 'n goeie

12 Die US Taalbeleid (2016) is ' $n$ volwaardige akteur en is baie prominent in die netwerk. Die beperkte lengte van hierdie artikel maak egter 'n deurtastende bespreking daarvan onmoontlik. 
verhouding met die tolke aanvoel dat hulle dalk sukkel om te hoor, herhaal die vrae. In gevalle waar vrae nié herhaal word nie, is dit dikwels die tolk se vakkennis wat haar in staat stel om die vraag korrek te antisipeer. Haar hulptolk kan haar ook dalk help.

Die assosiasie of verwantskappe tussen verskillende akteurs - hetsy menslik (dosent, student, tolk) of niemenslik (die lokaal, akoestiek, vakgebied, Taalbeleid) - bepaal die proses, en uiteindelik ook die sukses of mislukking van die tolking. 'n Spesifieke tolk wat in 'n sekere verhouding tot die vakgebied en haar gebruiker(s) staan, kan dit as deel van haar rol beskou om aspekte vir haar gebruiker op te helder en die bronteks aan te vul. In hierdie proef het die tolk byvoorbeeld die Latynse frase conditio sine qua non herhaal, en bygevoeg "sonder 'n c" omdat sy weet dat die term dikwels verwar word met condictio, wat na 'n ander konsep verwys. Net hierna wys die dosent dieselfde aspek aan die res van die klas uit en waarsku hulle om nie die twee terme te verwar nie. Die spesifieke konfigurasie en interaksie of assosiasie van rolspelers in hierdie geval kon dalk gebruikers se vertroue in die tolkproduk verhoog. Hoewel tolke dikwels deur etiekkodes aangesê word om niks by die bronteks by te voeg nie en 'elke woord te tolk', lyk die realiteit heelwat anders. Volgens Buzelin (2005) is 'n vergestalting van die nut van 'n ondersoek binne die ANT-raamwerk die identifisering van die mate waarin tolke norme gehoorsaam of bevraagteken. In werklikheid is dit soms juis hierdie invoegings wat waarde vir gebruikers toevoeg en tot groter werksbevrediging by tolke lei.

Waar daar in die tolkproses tekens van oormatige inspanning ${ }^{13}$ by tolke was, was 'n sekere kombinasie van rolspelers dikwels betrokke. Die moeilikheidsgraad van die vakgebied (akteur) tesame met die dosent se praatspoed (akteur) of idiomatiese taalgebruik (akteur) laat die tolk soms faal ten opsigte van toon en ritme, ook vanweë die spesifieke tolk (akteur) se eie geneigdheid om vinnig te praat. Die tolk se kennis van die vakgebied (akteur) kon dikwels die inspanning help verminder of haar beskikbare linguistiese repertoire help vergroot. ${ }^{14}$

Akteurs wat prominent in die administrasie van die tolkprogram staan en na verwagting 'n belangrike rol in die netwerk sou speel, was nie baie prominent in die data nie. Lokale het in enkele gevalle weens swak akoestiek gefigureer. Artefakte soos aanlyn woordeboeke of Google Translate het slegs enkele kere voorgekom. Woordelyste en voorbereidingsmateriaal het selde 'n rol gespeel. Tolke het nie van SUNLearn ${ }^{15}$ gebruik gemaak nie. MS PowerPoint-aanbiedings en konsepkaarte ${ }^{16}$ het wel voorgekom omdat tolke in die tolkproses terme daarvan aflees. Dit was nie altyd nuttig nie omdat probleemterme dikwels nie vakterme was nie, of omdat die terme en die vertalings nie in alle gevalle in die skyfies voorgekom het nie. In ander gevalle was dit weer baie waardevol omdat terme konsekwent in die bron- én die doeltaal voorgekom het. Dít, tesame met die tolke se vakkennis, het die waarde van woordelyste en voorbereidingsmateriaal beperk. Daarbenewens was sommige akteurs sigbaar in die netwerk, maar het hulle nie werklik 'n invloed gehad nie. Google Translate is soms geraadpleeg, maar het selde waardevolle oplossings gebied. Soms het die hulptolk die res van die Taalsentrum se tolkspan op hulle Whatsapp-groep om hulp gevra, maar wanneer dit uiteindelik beskikbaar was, was die oomblik reeds verby en was geen verdere aksie in die netwerk sigbaar nie.

13 Hierdie term verwys na Gile (1995:169) se effort model (in Afrikaans vertaal as 'inspanningsmodel').

14 Verwys na Gile se gravitasiemodel (1995:212).

15 SUNLearn is 'n aanlyn portaal met studiemateriaal en inligting vir studente. Tolke het toegang hiertoe.

16 Konsepkaarte word in Strafreg 171 gebruik, en is 'n skematiese voorstelling van belangrike konsepte en die verwantskappe daartussen. 
Die tolkrooster is normaalweg 'n belangrike akteur. In die geval van tolking in die Fakulteit Regsgeleerdheid tree die rooster egter as 'n blote tussenganger op omdat die tolke ál die modules hier konsekwent tolk en nie die rooster hoef te raadpleeg nie. Die rooster as akteur is sigbaar in die netwerk, maar het geen werklike verdere aksie (of spoor) tot gevolg nie. Tog is die rooster vir sommige van die ander tolke in die Taalsentrum se tolkspan 'n baie belangrike akteur. Sommige tolke moet op kort kennisgewing vir ander tolke instaan en in vakke tolk waarvan hulle weinig indien enige tolkervaring het. In sy verduideliking van mediators verduidelik Latour (2005:59) dat hierdie akteurs dikwels 'n "concatenation of new mediators" in die netwerk tot gevolg het en nuwe, onverwagse akteurs na vore laat tree. Op hierdie manier tree die rooster soms tipies as volwaardige akteur én mediator in die netwerk op.

Ook gebruikers tree dikwels as blote tussengangers op. 'n Gebruiker kom die klas binne, sit sy of haar studentekaart neer, neem 'n ontvanger en oorfoon, gee ná die tyd die toerusting terug, neem weer sy of haar studentekaart en stap uit. Dit was opmerklik hoe selde die gebruikers in die netwerk as volwaardige akteurs gefigureer het en nie net as blote as tussengangers opgetree het nie. Hier is die waarde van ANT ooglopend. ANT handel oor áksie; iets moet gebeur. Die data beklemtoon dat die gebruiker se invloed in die netwerk te gering is en dat die interaksie tussen tolke en gebruikers moet verhoog. In tolkteorie is gebruikers een van die belangrikste rolspelers, en behels 'rol' juis die verhouding van tolke teenoor hulle gebruikers. Die realiteit blyk egter hiervan te verskil. In aansluiting met die spanning tussen praktyk en teorie wat hier vergestalt word, sê Gad en Bruun Jensen (2010:61) van teoretiese konsepte: "Such abstractions are too broad to precisely capture the circumstances of local practice."

Kotzé (2012:146) het bewyse gevind van 'n wending na 'n meer sosiaal-dinamiese rolmodel vir tolking en van die veranderlike aard van die rol van die opvoedkundige tolk. Turner (2004:183) wys daarop dat die tolk deel is van die sosiale proses van onderrig en leer, sowel as van interaksie tussen dosent en student. In die data was daar tekens dat tolke die behoefte ingesien het om die kommunikasie binne te dring en aktief daaraan deel te neem. Ongelukkig kan tolke dikwels nie optimale begrip by studente fasiliteer nie. In die groter konteks van die leerproses is tolke dikwels slegs tussengangers deurdat hulle vertaalekwivalente vir byvoorbeeld regsterme kan gee, maar nie volwaardige akteurs in die kommunikasie kan wees nie.

\section{Slotsom}

Buzelin (2007:163) moedig navorsers aan om waarnemings in die netwerk te vergelyk met hulle realiteit, en om dan te kyk in watter mate dít insiggewend is vir die ontwikkeling van teorie. Sy kom terselfdertyd tot die gevolgtrekking dat daar ook buite die netwerk 'n voorafbepaalde 'struktuur' of 'breër patroon' sigbaar is. In die konteks van hierdie studie kan dit dalk na die rol van taal teen die agtergrond van die breër Suid-Afrikaanse politieke werklikheid en die hegemonie van Engels verwys. Sy sien egter bewyse daarvan dat hierdie breër verwantskappe 'n invloed op die netwerk het, en meen dat netwerkstudies juis hiér relevant is vir 'n ondersoek na opvoedkundige tolking as sosiaal bepaalde aktiwiteit (2007:165).

Hierdie projek het tolking in net een fakulteit, in een taalkombinasie en met een span tolke ondersoek. Hoewel die bevindings nie veralgemeen kan word nie, was dit opmerklik dat data uit al vier modules grootliks ooreengestem het. Taalbeplanners en -bestuurders kan hierdie data raadpleeg en pragmaties te werk gaan om werkbare oplossings vir probleme te vind. Buzelin (2007:163) reken werkplekstudies bied 'n geleentheid om deskriptiewe vertaalstudie met die 
oogmerke en doelwitte van tolkopleiding in verband te bring omdat dít die implikasies en die kompleksiteit van (opvoedkundige) tolking sal toon. Gile (2001:25) stem hiermee saam, maar voer aan dat die groter doel van navorsing uiteindelik is om tolke se status in hulle werkplek te verhoog. In opvoedkundige tolking is dit belangrik dat navorsingsbevindings in die praktyk tot die lewering van 'n kwaliteitproduk sal meewerk. Uiteindelik bly ons doelwit om na die belange van ons kliënte om te sien en meertaligheid aan die US te implementeer.

\section{Bronnelys}

Buzelin, H. 2005. Unexpected allies: How Latour's network theory could complement Bourdesian analyses in translation studies. The Translator 11(2): 193-218.

Buzelin, H. 2007. Translations in the making. In M. Wolf en A. Fukari (reds.) Constructing a sociology of translation. Amsterdam en Filadelfia: John Benjamins. pp. 135-169.

Chang, C. 2005. Directionality in Chinese/English simultaneous interpreting: Impact on performance and strategy use. Ongepubliseerde doktorale proefskrif, Universiteit van Texas, Austin, VSA.

Chernov, G.V. 2004. Inference and anticipation in simultaneous interpreting. Amsterdam en Filadelfia: John Benjamins.

Flynn, P. 2010. Ethnographic approaches. In Y. Gambier en L. van Doorslaer (reds.) Handbook of Translation Studies Vol. 1. Amsterdam en Filadelfia: John Benjamins. pp. 116-119.

Gad, C. en C. Bruun Jensen. 2010. On the consequences of post-ANT. Science, Technology, \& Human Values 35(1): 55-80.

Geertz, C. 1973. The interpretation of cultures. Vol. 5019. New York: Basic Books.

Gile, D. 1995. Basic concepts and models for interpreter and translator training. Amsterdam en Filadelfia: John Benjamins.

Gile, D. 2001. Interpeting research. Aanlyn beskikbaar: https://aiic.net/page/341/interpretingresearch/lang/1 (18 April 2017).

Kotzé, H. 2012. 'n Ondersoek na die veranderlike rol van die opvoedkundige tolk. Ongepubliseerde doktorale proefskrif, Noordwes-Universiteit, Potchefstroom, Suid-Afrika.

Latour, B. 2005. Reassembling the social: An introduction to Actor Network Theory. New York: Oxford University Press.

Mol, A. 2010. Actor-Network Theory: Sensitive terms and enduring tensions. Kölner Zeitschrift für Soziologie und Sozialpsychologie Spesiale uitgawe 50: 253-269.

Pöchhacker, F. 1996. Slips and shifts in simultaneous interpreting. In J. Tommola (red.) Topics in interpreting research. Turku: Universiteit van Turku. pp. 73-90.

Pöchhacker, F. 2006. "Going social?" On pathways and paradigms in interpreting studies. In A. Pym, M. Shlesinger en Z. Jettmarová (reds.) Sociocultural aspects of translating and interpreting. Amsterdam en Filadelfia: John Benjamins. pp. 215-232.

Pollner, M. en R.M. Emerson. 2001. Ethnomethodology and ethnography. In P. Atkinson, A. Coffey, S. Delamont, J. Lofland en L. Lofland (reds.) Handbook of ethnography. Londen: Sage. pp. 118-135. 
Turner, G.H. 2004. Professionalisation of interpreting with the community: Refining the model. In C. Wadensjö, B.E. Dimitrova en A. Nilsson (reds.) The critical link 4. Amsterdam en Filadelfia: John Benjamins. pp. 181-192.

US (Universiteit Stellenbosch). 2016. Taalbeleid van die Universiteit Stellenbosch. Aanlyn beskikbaar: http://www.sun.ac.za/english/Documents/Language/Finale\%20Junie\%20Taalbeleid\%20November\%2 02016.pdf (25 April 2017). 